Weronika Krajniak (Archiwum Uniwersytetu Mikołaja Kopernika w Toruniu) mgr, krajniak@umk.pl

ORDCID iD: 0000-0002-4931-1876

\title{
Co kryją spuścizny przechowywane w zasobie Archiwum Uniwersytetu Mikołaja Kopernika w Toruniu?
}

Analizując dokumentację Archiwum Uniwersytetu Mikołaja Kopernika w Toruniu (dalej: Archiwum UMK), użytkownik natknie się z pewnością na archiwa osobiste pracowników naukowych i administracyjnych uczelni, a także na nieliczne spuścizny osób formalnie niezwiązanych z UMK. Mowa tu o materiałach Krystyny Porębskiej-Rożałowskiej, pracownicy Towarzystwa Naukowego w Toruniu oraz Henrietty i Friedricha Lange, administratorów nieruchomości przy dawnej ul. Św. Jerzego 48 (obecnie ul. K.I. Gałczyńskiego 48). Zasób dotyczący materiałów osobistych jest niezwykle ciekawy i z całą pewnością zainteresuje niejednego naukowca w aspekcie badania dziejów ich twórcy, instytucji, historii nauki, ale także zwykłego poszukiwacza ciekawostek. Dzięki dokumentom znajdującym się w spuściznach, możemy prześledzić, choć jest to możliwe tylko wtedy, gdy mamy do czynienia ze spuścizną kompletną, działalność naukową, dydaktyczną, a także społeczną danej osoby. Niekiedy napotkamy bogatą i obszerną korespondencję służbową oraz prywatną, materiały warsztatowe, w których znajdują się maszynopisy, ręcznie sporządzone notatki i dopiski.

Artykuł napisany został na marginesie prac oraz własnych przemyśleń związanych z przygotowywaniem informatora o zasobie Archiwum UMK, wydanym z okazji jubileuszu siedemdziesięciolecia tej instytucji ${ }^{1}$. Autorka niniejszego tekstu zajmowała się w tym projekcie rozdziałem poświęconym spuściznom pracowników i osób związanych z UMK. Podczas prac szczegółowo zapoznała się nie tylko ze spisami zdawczo-odbiorczymi i inwentarzami, ale

${ }^{1}$ Archiwum Uniwersytetu Mikołaja Kopernika w Toruniu. Informator o zasobie archiwalnym (Stan na dzień 31 grudnia 2017 roku), pod red. A. Supruniuk, W. Krajniak, Toruń 2018. 
także z zaciekawieniem przeglądała zawartość poszczególnych teczek, odkrywając na nowo wiele cennych materiałów. Artykuł jest także podsumowaniem wieloletniej już tradycji przejmowania spuścizn po toruńskich uczonych ${ }^{2}$. Do tej pory nigdzie nie zaznaczono, poza wspomnianym już informatorem, że zasób Archiwum UMK sięga końca XVIII w. Przeoczenie wynika z faktu, że w datacji nigdy nie uwzględniano materiałów znajdujących się w spuściznach. A przecież te archiwa osobiste również tworzą zawartość magazynów.

Archiwum UMK do 2020 r. zgromadziło w swoim zasobie 82 spuścizny archiwalne po pracownikach Uniwersytetu oraz osobach związanych z uczelnią, w tym 59 spuścizn profesorów, cztery spuścizny po docentach i doktorach habilitowanych, osiem spuścizn po doktorach, dziesięć po magistrach i jedna po Henrietcie i Friedrichu Lange, administratorach obiektu, o których wykształceniu nic nie wiemy. Biorąc pod uwagę ogólny profil naukowy, dominują materiały historyków (22 spuścizny), filologów/lektorów języka (11), biologów (8), prawników i geografów (po 6), artystów, astronomów i chemików (po 5). Mniejszą grupę stanowią spuścizny filozofów i matematyków (po 2) oraz pojedyncze podzespoły, m.in.: architektów, bibliotekarzy, lekarzy, dyrygentów i ekonomistów. Materiały te są wydzielonymi podzespołami kwalifikowanymi do wieczystego przechowywania. Łącznie składają się na ponad 180 metrów bieżących akt. Początki gromadzenia spuścizn w archiwum sięgają roku 1966, kiedy decyzją urzędującej kierowniczki doc. Ireny Janosz-Biskupowej przejęto materiały po prof. Jadwidze Lechickiej, historyczce, badaczce dziejów nowożytnych, historii oświaty i metodyki nauczania historii. Pod koniec 1972 r. poza wspomnianą już spuścizną wymieniano także materiały po dr. Adamie Dygdale i prof. Tadeuszu Czeżowskim³ ${ }^{3}$ Na końcu arty-

2 Podobnego podsumowania bibliotecznych zbiorów spuścizn dokonał ostatnio A. Mycio, Opracowanie archiwów prywatnych w Sekcji Rękopisów Biblioteki Uniwersyteckiej w Toruniu, „Archeion" 2018, t. 119, s. 233-244. Zob. też: M. Jabłońska, B. Kierzkowska, Spuścizny archiwalne kobiet uniwersytetu w zasobie Archiwum Uniwersytetu Mikotaja Kopernika w Toruniu i Bibliotece Uniwersyteckiej, [w:] Niewidzia(l)ne. Kobiety i historia Uniwersytetu Mikołaja Kopernika w Toruniu, red. A. Derra, A.M. Kola, W. Piasek, Toruń 2020, s. 227-257.

${ }^{3}$ Archiwum Uniwersytetu Mikołaja Kopernika (dalej: AUMK), Akta własne - kontrola zewnętrzna [Archiwum Państwowe] (1953-2003), sygn. 2002/11, Protokół wizytacji składnicy akt, dnia 29 IX 1966 r.; tamże, Protokół wizytacji Archiwum Uniwersytetu Mikołaja Kopernika w Toruniu przeprowadzonej w dniu 13 XII 1972 r.; A. Supruniuk, W. Krajniak, Wstęp, [w:] Archiwum Uniwersytetu Mikołaja Kopernika w Toruniu. Informator o zasobie archiwalnym, s. 34; więcej o zasobie i historii Archiwum UMK zob. m.in.: W. Krajniak, Rys historyczny Archiwum Uniwersytetu Mikotaja Kopernika w Toruniu, "Przegląd Archiwalno-Historyczny" 2017, t. 4, s. 153-164; H. Duczkowska-Moraczewska, Wykaz materiałów pracowników naukowych i dydaktycznych Uniwersytetu Mikotaja Kopernika w zbiorach Archiwum i Biblioteki UMK, [w:] Polsko-litewskie kontakty naukowe w świetle zbiorów archiwalnych i bibliotecznych, red. J. Arvaniti, A. Roszkowski, Warszawa 2004, s. 115-131; I. Janosz-Biskupowa, Archiwum Uniwersytetu M. Kopernika (19481968), ,"Zeszyty Naukowe Uniwersytetu Mikołaja Kopernika w Toruniu. Nauki Humanistyczno-Społeczne. Historia" 1969, t. 5(36), s. 69-91. 
kułu została załączona tabela z wykazem wszystkich spuścizn znajdujących się w zasobie Archiwum.

Archiwa osobiste należały przeważnie do osób już nieżyjących. Dokumenty zostały przekazane przez jednostki, w których osoby te pracowały, bądź była to decyzja rodziny zmarłego. We wcześniejszych latach sporadycznie można spotkać przypadki, gdy spadkodawcy za życia wybrali magazyny Archiwum Uniwersyteckiego na miejsce przechowania ich dorobku. Obecnie coraz częściej pracownicy Archiwum UMK spotykają się z darowizną materiałów za życia. Fakt ten głównie podyktowany jest wyborem miejsca, gdyż wiele osób uważa, że najlepszym ulokowaniem dokumentacji jest archiwum. Dominuje wreszcie chęć pozostawienia swojego dorobku w instytucji, w której nierzadko spędziło się większość swojego życia, a także troska o dokumentację, która po śmierci mogłaby zostać rozproszona lub, co gorsza, wyrzucona na makulaturę. Zdarzają się również przypadki, w których przekazujący spuściznę posiada tak obszerne archiwum osobiste, że zwyczajnie nie mieści się ono już w jego służbowym bądź domowym gabinecie. Materiały przejmowane są partiami, w formie darowizny. Tylko spuścizna Janiny Gardzielewskiej, toruńskiej fotografki została zakupiona przez Uniwersytet. Rzadko zdarzają się spuścizny kompletne, posiadające pierwotny układ nadany przez twórcę. Przykładem takich spuścizn mogą być materiały po prof. Jerzym Serczyku ${ }^{4}$, $\mathrm{w}$ których $\mathrm{w}$ trakcie porządkowania wprowadzono niewielkie zmiany, a także po prof. Leonie Jeśmanowiczu. W pozostałych przypadkach trudno mówić o porządku nadanym przez aktotwórcę. Dlatego też żmudna i pracochłonna praca przy porządkowaniu i opracowywaniu spuścizny powoduje, że większość z nich posiada jedynie spisy zdawczo-odbiorcze.

Pracownicy Archiwum UMK opracowują spuścizny rękopiśmienne według wytycznych Polskiej Akademii Nauk, które do dziś stanowią normę $\mathrm{w}$ postępowaniu $\mathrm{z}$ tego typu materiałami ${ }^{5}$, wprowadzając jednie małą zmianę dotyczącą umiejscowienia dokumentów biograficznych w serii pierwszej, a nie jak proponują wytyczne - w serii trzeciej. Zrezygnowano także z podziału na korespondencję wychodzącą i wchodzącą. Porządkowana jest ona w układzie alfabetyczno-chronologicznym. Obecnie, z uwagi na niewystarczającą ilość miejsca w magazynach, a także z powodu braku odpowiednich warunków i fizyczną postać, nie są przejmowane księgozbiory, a także wielkogabarytowe eksponaty - wyjątek stanowią najcenniejsze i najbardziej

\footnotetext{
${ }^{4}$ Więcej o tej spuściźnie zob.: W. Krajniak, Jerzy Serczyk i jego materiaty w zasobie Archiwum Uniwersytetu Mikotaja Kopernika w Toruniu, „Archeion” 2018, t. 119, s. 331-348.

${ }^{5}$ Wytyczne nr 12 Polskiej Akademii Nauk z 1990 r. dotyczące opracowania spuścizn archiwalnych po uczonych, zob. Zbiór przepisów archiwalnych wydanych przez Naczelna Dyrekcje Archiwów Państwowych w latach 1952-2000, wybór i oprac. M. Tarakanowska, E. Rosowska, Warszawa 2001, s. 732-746.
} 
związane z twórcą. Za sugestią dyrektora Archiwum, materiały te trafiają do Biblioteki Uniwersyteckiej UMK lub Muzeum Uniwersyteckiego UMK.

Materiały osób żyjących udostępniane są tylko i wyłącznie za pisemną ich zgodą. Nieco inaczej wygląda to w przypadku osób nieżyjących. Wtedy archiwum bierze pod uwagę przepis z kodeksu cywilnego mówiący o ochronie dóbr osobistych, tzw. kulcie pamięci po osobie zmarłej, a takie prawo do ochrony tego dobra przysługuje żyjącym bliskim. W obu sytuacjach udostępnienie akt spuścizny następuje po wypełnieniu wniosku o udostępnienie materiałów archiwalnych ${ }^{6}$.

Spuścizny to nie tylko dokumentacja rękopiśmienna, na którą składają się materiały warsztatowe, korespondencja, dokumentacja biograficzna etc. To również: fotografie, nagrania audiowizualne, medale i odznaczenia, dyplomy, mapy i liczne kurioza, które niekiedy są zaskakujące. Przyjrzyjmy się zatem, co ciekawego kryją spuścizny po pracownikach UMK oraz osobach z nim związanych. Analizie zostały poddane tylko wybrane archiwa osobiste.

Materiały archiwalne ze spuścizny mgr Marii Alexandrowicz stanowią doskonałe źródło do poznania jej działalności i zainteresowań turystycznych. Zachowała się bogata dokumentacja Koła Polskiego Towarzystwa Turystyczno-Krajoznawczego działającego przy UMK, w którym Alexandrowicz prężnie działała. Materiały te dotyczą wycieczek krajoznawczych organizowanych przez Towarzystwo w latach 1961-1985. Wśród nich znajdziemy opisy i mapy podróży, liczne fotografie, a także rozliczenia finansowe i sprawozdania. Alexandrowicz interesowała się czynnie życiem całego Uniwersytetu, czego odzwierciedleniem są wycinki prasowe, pieczołowicie gromadzone przez lata (1946-1983). Ponadto w spuściźnie odnajdziemy listy dzieci pisane do redakcji „Małego Gryfa”, dodatku dla dzieci w „Robotniku Pomorskim”, później w "Głosie Pomorskim”, oraz wydane numery gazetki dziecięcej, w której była redaktorką. Twórczyni materiałów żywo zajmowała się teatrem, czego odbiciem są jej felietony i reportaże związane z problematyką kultury oraz afisze teatralne pochodzące $\mathrm{z}$ różnych krajów ${ }^{7}$.

W materiałach prof. Mariana Biskupa ciekawe dla badaczy średniowiecza wydają się kserokopie, reprodukcje i odpisy źródeł dotyczące Mikołaja Kopernika, Zakonu Krzyżackiego oraz akt Stanów Pruskich z Ordensbriefarchiv, znajdujących się w Geheimes Staatsarchiv Preußischer Kulturbesitz w Berlinie, i akt Prus Królewskich, a także materiały z Deutsches Orden Zentralarchiv w Wiedniu, Hauptsarchiv w Monachium i Staatsarchiv

${ }^{6}$ Formularz dostępny na stronie Archiwum UMK: https://www.archiwum.umk.pl/za sob/regulamin-udostepniania-i-formularze/(dostęp: 1 listopada 2020 r.).

${ }^{7}$ Spuścizna mgr Marii Alexandrowicz 1899-1985, AUMK sygn. 309/73; zob. też: M. Jabłońska, B. Kierzkowska, dz. cyt., s. 234-235; W. Krajniak, Spuścizny po pracownikach Uniwersytetu oraz osobach zwiazanych z Uczelnia, [w:] Archiwum Uniwersytetu Mikotaja Kopernika w Toruniu. Informator o zasobie archiwalnym, s. 289-290; H. Duczkowska-Moraczewska, dz. cyt., s. 115-131. 
w Dreźnie. Ponadto w spuściźnie znajdują się źródła kartograficzne dotyczące m.in. Torunia, Bydgoszczy, Gdańska, Wilna i Inflant. Aktotwórca zgromadził obszerną korespondencję prywatną i służbową z lat 1953-2010 oraz bogatą kolekcję nadbitek artykułów z dedykacjami z lat 1947-2007, które w magazynie Archiwum UMK składają się na 42 tomy. Ponadto w spuściźnie jest kilka numerów „Thorner Nachrichter” z lat 1976-2007 i „Preussenland” z lat 19632005 oraz „Atlas Historyczny Miast Polskich". Ciekawy jest także zbiór medali i odznaczeń, które M. Biskup otrzymywał za swoje zasługi i działalność ${ }^{8}$.

Jedną z pierwszych przyjętych i największych spuścizn przechowywanych w Archiwum UMK są materiały po prof. Tadeuszu Czeżowskim, filozofie i logiku, badaczu semantyki i metodologii nauki, które zainteresować mogą m.in. badaczy wileńskich korzeni UMK oraz filozofów. Wśród materiałów biograficznych odnajdziemy szereg legitymacji, kart i zezwoleń, w tym m.in. kartę Taternika Polskiego Związku Alpinizmu nr 36, a także przepustkę z 1918 r. od Miejskiej Straży Obywatelskiej, zezwalającą na swobodne poruszanie się po mieście Lwowie po godzinie 22. W dokumentacji z działalności organizacyjnej, dydaktycznej i wydawniczej znajdują się księgi, listy potrąceń i rozliczenia finansowe Biura Administracyjnego Uniwersytetu Stefana Batorego (dalej: USB) w Wilnie z lat 1933-1939, a także materiały Stowarzyszenia Grona Nauczycielskiego USB z lat 1924-1939, Wileńskiego (1928-1939) i Toruńskiego Towarzystwa Filozoficznego (1948-1975), Chóru Akademickiego USB (1931-1937). Ponadto znajdują się tam materiały dotyczące organizacji i funkcjonowania Koła Filozoficznego Studentów USB z lat 1922-1939 oraz Seminarium Filozoficznego UMK z lat 1946-1958. Profesor poświęcał czas także działalności społecznej, czego odzwierciedleniem są materiały aktowe i fotograficzne wileńskiego oddziału Polskiego Towarzystwa Tatrzańskiego (1923-1939). Aktotwórca był również zaangażowany w prace komitetu wydawniczego Pism Kazimierza Twardowskiego i Polskiego słownika filozoficznego. Obszerną część spuścizny stanowi korespondencja prywatna i służbowa, która została zgromadzona w latach 1914-1982. Składa się na nią aż 47 tomów! Nie sposób wymienić tu korespondencji z wszystkimi znanymi postaciami, ale warto wspomnieć o wyżej już wymienionym K. Twardowskim, a poza tym: Henryku Elzenbergu, Romanie Witoldzie Ingardenie czy Stanisławie Pigoniu. $Z$ materiałów rodzinnych zachował się certyfikat szlachectwa, metryki członków rodziny oraz dokumenty dotyczące majątku Hryhorowicze, położonego w powiecie dziśnieńskim województwa

8 Spuścizna prof. Mariana Biskupa 1933-2012, AUMK, sygn. 309/75; zob. też: W. Krajniak,Spuścizny po pracownikach Uniwersytetu..., s. 290-291; H. Ciechanowski, Spuścizna prof. Mariana Biskupa znajdujaca się w Archiwum Uniwersytetu Mikołaja Kopernika w Toruniu, http:/ / www.archiwa.net/index.php?option=com_remository\&Itemid=35\&func=startdown \&id=14 (dostęp: 30 marca 2019 r.); zob. też: materiały po Marianie Biskupie w zasobie Archiwum Państwowym w Toruniu, sygn. 69/598. 
wileńskiego. Wartościowy wydaje się także zbiór map topograficznych i informatorów turystycznych. Najstarsze mapy pochodzą z 1873 r. i 1975 r., dotyczą one powiatu Neunkirchen w Austrii i Drohobyczu w Ukrainie9.

Kolejną interesującą spuścizną jest z pewnością archiwum prof. Władysława Dziewulskiego, w którym miłośnicy astronomii odnajdą zeszyty obserwacyjne z pierwszych lat pracy aktotwórcy, a także późniejsze, drukowane w Polskiej Akademii Umiejętności w Krakowie oraz w "Astronomische Nachrichten". Ponadto zachował się skrypt z fizyki i tablice logorytmiczne z Uniwersytetu Warszawskiego oraz odczyty radiowe Niebo zimowe doc. Stanisława Szeligowskiego z lat 1927-1932. Na trzy tomy składają się publikacje profesora z lat 1906-1962. Najliczniejszą grupę stanowią materiały dotyczące Wydziału Matematyczno-Przyrodniczego UMK oraz Obserwatorium Astronomicznego w Piwnicach koło Torunia. Wśród tej grupy akt znajduje się także spis wyposażenia Obserwatorium USB w Wilnie ${ }^{10}$.

W spuściźnie prof. Rajmunda Galona znajduje się pokaźna liczba fotografii, które uwieczniają wyprawy, wycieczki i wyjazdy w Polsce oraz do krajów europejskich i Ameryki Południowej, a także z różne uroczystości, w których brał udział profesor. Przykładami są albumy z nadania profesorowi doktora honoris causa UMK w 1983 r. oraz ze zdjęciami przedwojennego Berlina i Poczdamu. W spuścí́nie znajdujemy także fotografie materiałów dydaktycznych i warsztatowych dotyczących form powierzchni ziemi, stratygrafii i chronologii zlodowacenia Wisły z 1979 r. Aktotwórca zgromadził, z racji bycia geografem, znaczną liczbę folderów, przewodników i map. Poza naukowymi dokumentami w spuściźnie znajdują się również materiały rodzinne, np. listy rodziców z 1894 r., nuty ojca Lucjana z 1937 r., a także artykuły wspomnieniowe Galona - O życiu kulturalno-oświatowym w niektórych oficerskich obozach jenieckich $w$ Niemczech $w$ l. 1939-1945 oraz szkice wspomnień dotyczące Armii Poznań. W materiałach odnaleźć można również figurkę przedstawiającą profesora autorstwa Jadwigi Wilkoń-Michalskiej ${ }^{11}$.

${ }^{9}$ Spuścizna prof. Tadeusza Czeżowskiego 1831-2012, AUMK, sygn. 309/80, zob. też: W. Krajniak, Spuścizny po pracownikach Uniwersytetu..., s. 295-297; H. Duczkowska-Moraczewska, dz. cyt., s. 115-131; R. Karpiesiuk, Spuścizna rękopiśmienna Tadeusza Czeżowskiego, „Acta Universitatis Nicolai Copernici. Nauki Humanistyczno-Społeczne. Historia" 1991, t. 25(236), s. 99-112; tejże, Tadeusz Czeżowski w świetle toruńskich archiwaliów, [w:] Tadeusz Czeżowski (18891981): dziedzictwo idei: logika-filozofia-etyka, pod red. W. Tyburskiego i R. Wiśniewskiego, Toruń 2002, s. 311-317; Biblioteka Główna UMK, Dział Rękopisów, sygn. Rps. 1585-1640, 2377-2398, $4770-4774$.

10 Spuścizna prof. Władysława Dziewulskiego 1898-2012, AUMK, sygn. 309/82; zob. też: W. Krajniak, Spuścizny po pracownikach Uniwersytetu..., s. 298-299; Biblioteka Główna UMK, Dział Rękopisów, sygn. Rps. 4785 oraz materiały nieopracowane.

${ }^{11}$ Spuścizna prof. Rajmunda Galona 1894-1986, AUMK, sygn. 309/83; zob. też: W. Krajniak, Spuścizny po pracownikach Uniwersytetu..., s. 300-301; Biblioteka Główna UMK, Dział Rękopisów, sygn. Rps. 2435-2463. 
Przy przygotowywaniu Informatora wyłączono z materiałów Katedry i Zakładu Neurofizjologii i Fizjologii Porównawczej Wydziału Biologii i Nauk o Ziemi UMK spuściznę prof. Janiny Hurynowicz, przekazaną w 1982 r. przez prof. Leszka Janiszewskiego. Dokumentacja, którą wówczas przejęto jako zakładową, okazała się archiwum Hurynowicz. Wśród materiałów na uwagę zasługuje chociażby udokumentowana współpraca z Wojewódzką Przychodnią Zdrowia Psychicznego z lat 1964-1966, a także korespondencja $z$ doc. Napoleonem Baniewiczem, ordynatorem Oddziału Neurologii Szpitala Ogólnego w Bydgoszczy z lat 1945-1966, oraz doc. Józefem Sysą z Akademii Medycznej w Łodzi (1963-1964). Ponadto cennymi materiałami okazują się dokumenty dotyczące działalności organizacyjnej Zakładu Fizjologii Zwierząt z lat 1948-1964. Podobnie jak w spuściźnie R. Galona, także tu znajdujemy figurkę z podobizną Hurynowicz wykonaną przez J. Wilkon-Michalską. Dla badaczy Wilna i okolic wartościowa będzie z pewnością okazała kolekcja fotografiii ${ }^{12}$.

Kolejną spuścizną, zasługującą na poświęcenie kilku zdań, jest archiwum prof. Romana Stanisława Ingardena, fizyka i matematyka, specjalizującego się w optyce geometrycznej i dyfrakcyjnej, często mylonego z ojcem Romanem Witoldem, filozofem. Pokaźna, składająca się z 34 tomów korespondencja z lat 1953-2010, kryje w sobie listy m.in. prof. Wojciecha Rubinowicza, fizyka teoretyka. Materiały o nim odnajdziemy również w materiałach warsztatowych. Profesor interesował się kulturą Japonii, dlatego nie może dziwić, że wśród akt spuścizny znajdują się materiały do nauki języka japońskiego, fiszki z alfabetem japońskim, rozmówki audio oraz słowniki i podręczniki językowe. Wśród księgozbioru pozostawionego w spuściźnie odnajdziemy książkę $O$ zasadzie sprzeczności u Arystotelesa autorstwa Jana Łukaszewicza, wydaną w Krakowie w 1910 r., a także publikację niemieckiego fizyka Wernera Heisenberga Die Physikalischen Prinzipen der Quanten Theorie, wydaną w Lipsku w 1944 r. Poza wymienionymi już materiałami, uwagę zwraca kolekcja identyfikatorów z konferencji, w których uczestniczył profesor (124 sztuki) oraz wywiady z prof. Kazimierzem Antonowiczem, fizykiem, i prof. L. Jeśmanowiczem, matematykiem, które Ingarden przeprowadził wspólnie z prof. Sławomirem Kalembką, historykiem, 14 i 30 listopada 1977 r. ${ }^{13}$

Spuścizna prof. Wilhelminy Iwanowskiej stanowi źródło do poznania jej życia i działalności naukowej, a także dydaktycznej i organizatorskiej. W ar-

${ }^{12}$ Spuścizna prof. Janiny Hurynowicz 1938-1971, AUMK, sygn. 309/168; zob. też: M. Jabłońska, B. Kierzkowska, dz. cyt., s. 258; W. Krajniak, Spuścizny po pracownikach Uniwersytetu..., s. 307; Biblioteka Główna UMK, Dział Rękopisów, sygn. Rps. 1376-1409, 4784.

${ }^{13}$ Spuścizna prof. Romana Stanisława Ingardena 1910-2010, AUMK, sygn. 309/158; zob. też: W. Krajniak, Spuścizny po pracownikach Uniwersytetu..., s. 309-310. 
chiwum osobistym, przekazanym przez nią samą w 1996 r., ciekawe wydają się materiały dotyczące działalności UMK, w tym Instytutu Astronomii z lat 1967-1979, organizacji kierunku radioastronomii i Obserwatorium Astronomicznego UMK w Piwnicach koło Torunia. Warta uwagi jest „Kronika” wspomnianego już Obserwatorium z lat 1945-1995. Zachowała się również dokumentacja Komitetu Astronomii Polskiej Akademii Nauk, a także Międzynarodowej Unii Astronomicznej i Polskiego Towarzystwa Astronomicznego, w których Iwanowska prężnie działała. Ponadto w spuściźnie znajdują się foldery, programy i informatory ze spotkań naukowych, w których profesor brała udział. Materiały biograficzne zawierają m.in. dokumenty autobiograficzne, wycinki prasowe, nominacje i dyplomy. Poza tym są rzeczy osobiste, np. okulary i notatniki prywatne, a także doskonale zachowany epitage doktora honoris causa UMK, który W. Iwanowska otrzymała w 1973 r., oraz Krzyż Wielki Orderu Odrodzenia Polski Polonia Restituta, otrzymany w $1995 \mathrm{r}$. Wśród fotografii odnajdujemy: album z wodowania statku Uniwersytet Toruński, którego Iwanowska była matką chrzestną, zdjęcia z okresu wileńskiego z lat 1918-1941 oraz działalności organizacyjno-naukowej z lat 1946-1997. W tej spuściźnie znajdują się także kurioza, tj. rosyjska maszyna do liczenia "Feliks” z 1958 r. oraz narty, wyprodukowane w 1932 r. ${ }^{14}$ !

Jedną z niewielu spuścizn przekazanych przez pracowników administracyjnych są materiały mgr Haliny Jeśman, pracownicy dziekanatu Wydziału Humanistycznego, a później kierowniczki Działu Nauczania UMK. Dokumentacja w niej zawarta sięga roku 1868. Poza materiałami biograficznym i rodzinnymi, wśród których odnajdziemy: Krzyż Kawalerski Polonia Restituta nadany Jeśman, metryki ślubu i akt zgonu, znajdują się albumy fotograficzne $\mathrm{z}$ pięknymi zdjęciami przedwojennego Wilna, pracowników USB, a także powojennych wyjazdów wakacyjnych. Fotografie zostały opisane przez aktotwórcę. Wartościowe wydają się poza tym dwie publikacje z 1933 r., wydane w Wilnie przez profesora okulistyki Juliusza Szymańskiego pt. Atlasy Okulistyczne $e^{15}$.

Wybitną i ciekawą postacią był z pewnością prof. Leon Jeśmanowicz, matematyk specjalizujący się w metodologii nauczania matematyki, ale także karykaturzysta. Wśród stosów materiałów, jakie po sobie zostawił, odnajdziemy dokumenty z działalności organizacyjnej m.in. dotyczące ogólnopolskich Olimpiad Matematycznych dla uczniów szkół średnich, których przewodni-

14 Spuścizna prof. Wilhelminy Iwanowskiej 1918-2000, AUMK, sygn. 309/89; zob. też: M. Jabłońska, B. Kierzkowska, dz. cyt., s. 239-240; W. Krajniak, Spuścizny po pracownikach Uniwersytetu..., s. 310-311; Biblioteka Główna UMK, Dział Rękopisów, sygn. Rps. 4786 oraz materiały nieopracowane.

${ }^{15}$ Spuścizna mgr Haliny Jeśman 1868-1993, AUMK, sygn. 309/159; zob. też: M. Jabłońska, B. Kierzkowska, dz. cyt., s. 242; W. Krajniak, Spuścizny po pracownikach Uniwersytetu..., s. 314. 
czącym od 6. do 41. konkursu był właśnie L. Jeśmanowicz ${ }^{16}$. Ponadto w spuściźnie znajdują się dokumenty Polskiego Towarzystwa Matematycznego oraz protokoły z posiedzeń Komitetu Nauk Matematycznych PAN. Profesor poza tworzeniem rysunków i karykatur nie tylko naukowców, ale i osób ze świata kultury, pisywał także wiersze i scenariusze teatralne ${ }^{17}$. Gromadził również druki ulotne, tj. plakaty i afisze, broszury, kartki żywnościowe czy biuletyn z 1981 r. "Wolne Słowo"18.

Badacz biografii prof. Sławomira Kalembki z pewnością znajdzie materiały przydatne do jej napisania w jego spuściźnie. Głównie dotyczą one przebiegu życia i pracy naukowej, działalności dydaktycznej i materiałów warsztatowych. Poza tym interesujące są: bilety kolejowe, mapy, zdjęcia i pocztówki, czasopisma i wycinki z gazet z lat 1936-2009, związane z kolejnictwem, którego profesor był pasjonatem ${ }^{19}$.

Podczas opracowywania materiału do Informatora odkryto, że poza spuścizną prof. Józefa Kozłowskiego Archiwum jest w posiadaniu spuścizny prof. Barbary Narębskiej-Dębskiej-Kozłowskiej, jego małżonki. Również te materiały warte są odnotowania $\mathrm{w}$ powyższej publikacji. Obie spuścizny stanowią jedną, nierozerwalną całość. Ciekawą część tworzą materiały działalności naukowo-dydaktycznej jak np. informatory na temat Zakładu Kształcenia Form Plastycznych Wydziału Sztuk Pięknych UMK czy też kronika wystaw prac studentów. Ponadto w spuściźnie zachowały się katalogi i foldery wystaw, fotografie m.in. mebli i ekspozycji meblowych ze Spółdzielni Artystów „Rzut”, projekty plakatów i kompozycji przestrzennych J. Kozłowskiego oraz wystaw B. Narębskiej-Dębskiej-Kozłowskiej. Oboje profesorowie zbierali również wycinki prasowe na swój temat ${ }^{20}$.

Licząca niespełna dziesięć jednostek spuścizna Henrietty i Friedricha Lange, wspomnianych już wcześniej administratorów nieruchomości przy ul. K.I. Gałczyńskiego 48, obrazuje sądowy proces spadkowy z lat 1862, 18851944. Poza tym badacz wśród tych materiałów odnajdzie dokumentację techniczną, tj.: plany i rzuty budynku, pozwolenia na budowę, wygląd fasady. Zachowały się również dowody wpłat do kasy oszczędnościowej Starego

${ }^{16}$ A. Schinzel, Pięćdziesiąt lat Olimpiady Matematycznej, „Rocznik Polskiego Towarzystwa Matematycznego. Seria II: Wiadomości Matematyczne" 2000, t. 36, s. 155, 158.

17 A. Jędrzejczyk, Matematyka i karykatura. Pasje Leona Jeśmanowicza (1914-1989), ,"Konteksty: polska sztuka ludowa: antropologia kultury, etnografia, sztuka", 2020, r. 74, nr 1-2, s. 258-267.

${ }^{18}$ Spuścizna prof. Leona Jeśmanowicza 1927-1988, AUMK, sygn. 309/93; zob. też: W. Krajniak, Spuścizny po pracownikach Uniwersytetu..., s. 314-316.

${ }^{19}$ Spuścizna prof. Sławomira Kalembki 1936-2009, AUMK, sygn. 309/94; zob. też: W. Krajniak, Spuścizny po pracownikach Uniwersytetu..., s. 316-317; Biblioteka Główna UMK, Dział Rękopisów, sygn. Rps. 4319-4321, 4538-4580.

${ }^{20}$ Spuścizna prof. Józefa Kozłowskiego i prof. Barbary Narębskiej-Dębskiej-Kozłowskiej 1869-2010, AUMK, sygn. 309/97; zob. też: M. Jabłońska, B. Kierzkowska, dz. cyt., s. 247; W. Krajniak, Spuścizny po pracownikach Uniwersytetu..., s. 318-319. 
Miasta Torunia z roku 1944 oraz księgi domu z lat 1936-1937 i dokumentacja dotycząca eksmisji mieszkańców kamienicy z okresu II wojny światowej ${ }^{21}$.

Kolejną spuścizną należącą do artysty, ale tym razem malarza, badacza edukacji artystycznej, jest archiwum dr. Tadeusza Marciniaka. Jest to niewielka spuścizna, w której oprócz katalogów i plakatów wystaw indywidualnych z działalności artystycznej znajdują się też obrazy wykonane na płótnie przez aktotwórcę oraz dziecięce rysunki ${ }^{22}$.

Prof. Władysław Mrózek, geograf i badacz m.in. geologii, przekazując swoją spuściznę do archiwum w 1999 r., podarował głównie dokumentyosobiste, przedstawiające przebieg jego pracy zawodowej oraz działalności związkowej i społecznej. Interesujący dla badaczy wojskowości będzie dopływ spuścizny profesora przekazanej przez Instytut Geografii UMK w 2005 r. Wówczas dołączono do wcześniejszych dokumentów materiały wspomnieniowe, notatki, korespondencję oraz fotografie z niewoli niemieckiej z obozów w Sanbostel, Fürstenberg nad Odrą, Sudwalde i Delmenhorst. Ponadto wycinki prasowe i album fotograficzny z odbudowy Stacji Naukowo-Badawczej w Siemionkach z lat 1974-197623.

Kolejną spuścizną znajdującą się w magazynach Archiwum UMK są materiały mgr. Andrzeja Szwalbego, prawnika, a przede wszystkim działacza społecznego i kulturalnego, inicjatora budowy gmachu Filharmonii Pomorskiej oraz organizatora Bydgoskiego Towarzystwa Naukowego ${ }^{24}$.

Ostatnią omówioną spuścizną jest dokumentacja prof. Jana Michała Wieczorka, pedagoga, dyrygenta i kompozytora. Zawiera ona liczne materiały warsztatowe oraz prace aktotwórcy, w tym także rękopisy nut, np. Kantaty Kopernikańskiej oraz kantaty z okazji otwarcia Biblioteki Głównej UMK. W materiałach działalności twórcy spuścizny znajdują się również dzienniki i listy obecności z zajęć chóralnych, a także zbiór programów, plakatów i zaproszeń imiennych. Obszerna wydaje się korespondencja prywatna i służbowa m.in. z Zakładem Muzykologicznym Uniwersytetu Poznańskiego, Związkiem Kompozytorów Polskich, Polskim Radiem czy Związkiem Artystów i Kompozytorów Polskich z lat 1934-1983. W archiwum osobistym Wieczorka znajdziemy również materiały biograficzne, tj.: życiorysy i dokumenty osobiste z lat 1919-1946, dokumenty dotyczące przebiegu nauki i studiów z lat 19221965 oraz rodzinne $z$ lat 1947-1951. Ponadto zachowały się w nim liczne od-

${ }^{21}$ Spuścizna Henrietty I Friedricha Lange 1862-1944, AUMK, sygn. 309/180; zob. też: W. Krajniak, Spuścizny po pracownikach Uniwersytetu..., s. 320.

${ }^{22}$ Spuścizna dr. Tadeusza Jana Marciniaka 1976-2003, AUMK, sygn. 309/164; zob. też: W. Krajniak, Spuścizny po pracownikach Uniwersytetu..., s. 323-324.

${ }^{23}$ Spuścizna prof. Władysława Mrózka 1920-1999, AUMK, sygn. 309/103; zob. też: W. Krajniak, Spuścizny po pracownikach Uniwersytetu..., s. 326-327.

${ }^{24}$ Spuścizna mgr. Andrzeja Szwalbe 1996-2001, AUMK, sygn. 309/217; zob. też:W. Krajniak, Spuścizny po pracownikach Uniwersytetu..., s. 337-338. 
znaczenia i medale, znaczki i plakietki, szarfy i batuty oraz albumy fotograficzne, a także wycinki prasowe z działalności z latach 1922-193725.

$$
* * *
$$

Podsumowując niniejszy artykuł, należy zaznaczyć, że warte prezentacji są także pozostałe spuścizny, a wymienione $\mathrm{w}$ tekście są tylko namiastką tego, co znajduje się w zasobie Archiwum UMK. Należy również podkreślić, że wszystkie spuścizny stanowią doskonałą bazę źródłową w procesie poznania twórczości i działalności naukowej aktotówrców, a niekiedy historii danej instytucji. Archiwalia zgromadzone w archiwach osobistych mogą zostać wykorzystane przez badaczy wielu dziedzin w różnych aspektach nauki.

25 Spuścizna prof. Jana Michała Wieczorka 1904-1988, AUMK, sygn. 309/114; więcej zob. m.in.: W. Krajniak, Spuścizny po pracownikach Uniwersytetu..., s. 339-340. 


\begin{tabular}{|c|c|c|c|c|c|c|c|c|c|c|c|c|}
\hline 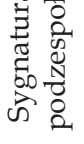 & $\frac{N}{\frac{N}{c}}$ & $\begin{array}{l}\frac{N}{N} \\
\text { के } \\
\text { के }\end{array}$ & $\begin{array}{l}\frac{10}{N} \\
\text { के } \\
\text { के }\end{array}$ & $\frac{0}{\stackrel{0}{~}}$ & $\begin{array}{l}\text { N } \\
\text { के } \\
\text { के }\end{array}$ & $\frac{\hat{N}}{\stackrel{N}{\sigma}}$ & $\frac{\infty}{\stackrel{\infty}{o}}$ & 站 & 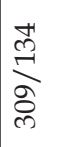 & $\begin{array}{l}\hat{N} \\
\text { के } \\
\text { के }\end{array}$ & $\frac{\stackrel{8}{\circ}}{\stackrel{\circ}{\circ}}$ & $\begin{array}{l}\frac{8}{\infty} \\
\frac{0}{0} \\
\text { के }\end{array}$ \\
\hline 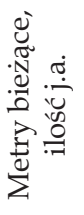 & 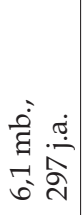 & 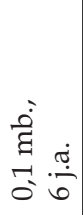 & 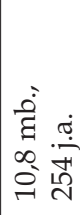 & 完 & 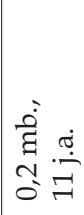 & 节 & 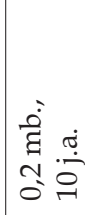 & 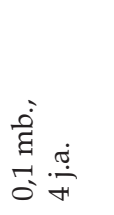 & 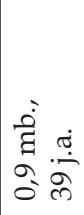 & 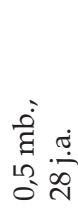 & 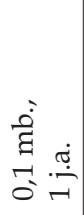 & 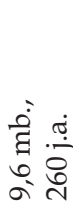 \\
\hline 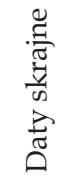 & 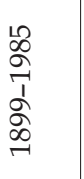 & 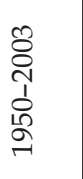 & 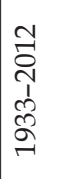 & 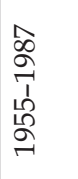 & 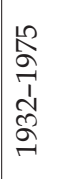 & 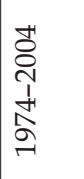 & $\begin{array}{l}0 \\
8 \\
1 \\
1 \\
0 \\
0 \\
2 \\
2\end{array}$ & 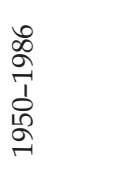 & 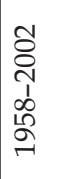 & 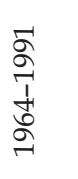 & 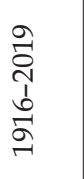 & 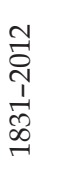 \\
\hline 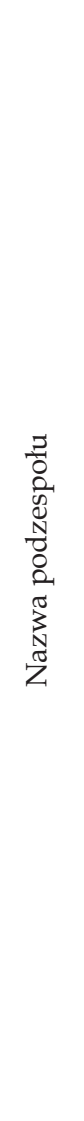 & 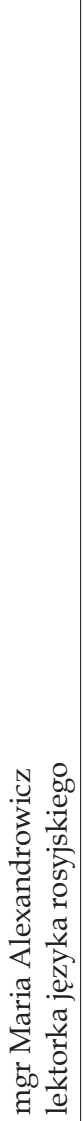 & 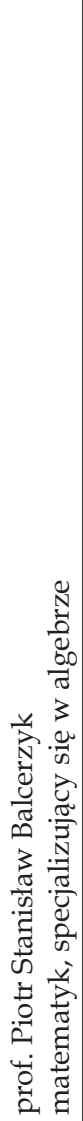 & 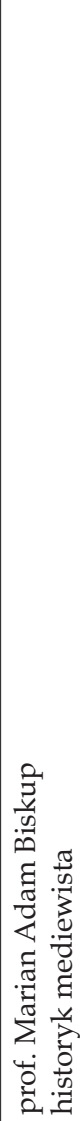 & 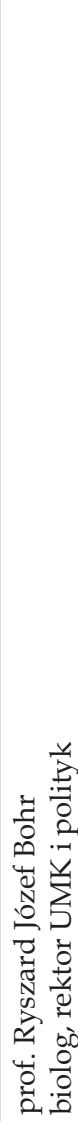 & 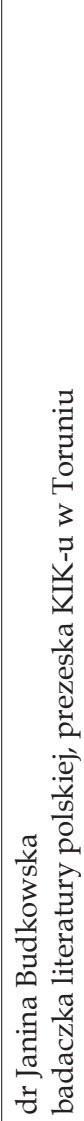 & 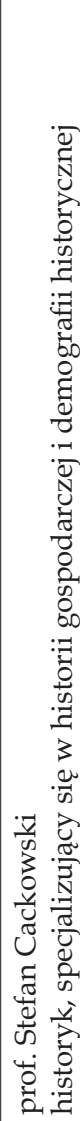 & 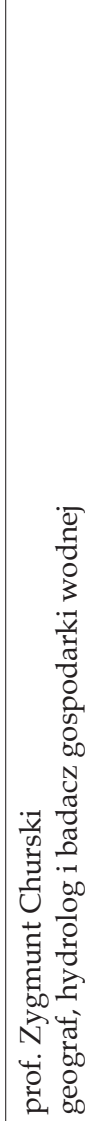 & 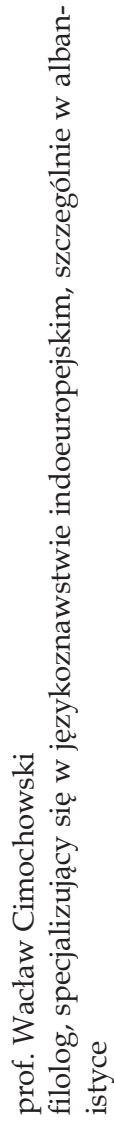 & 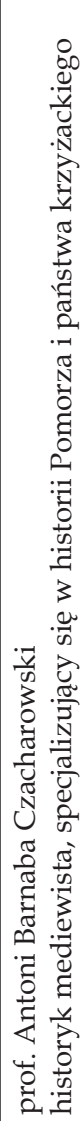 & 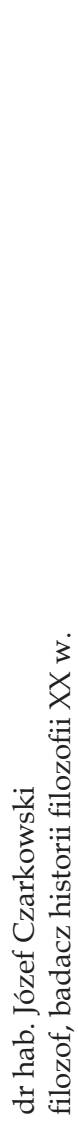 & 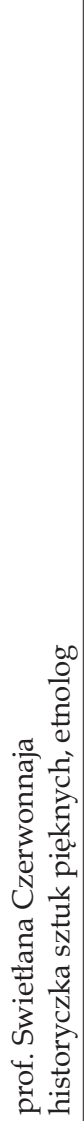 & 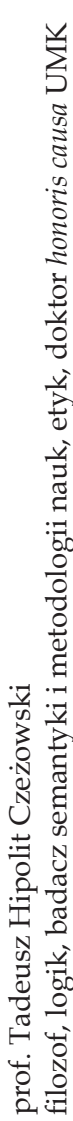 \\
\hline$\stackrel{\dot{2}}{3}$ & $\dot{\sim}$ & i & $\dot{\theta}$ & मi & $10^{\circ}$ & $0^{\circ}$ & $\wedge^{\circ}$ & $\infty$ & $\sigma^{\circ}$ & $\stackrel{\circ}{\circ}$ & $\exists$ & 구 \\
\hline
\end{tabular}




\begin{tabular}{|c|c|c|c|c|c|c|c|c|c|c|c|c|}
\hline 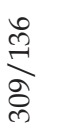 & $\frac{\infty}{\delta}$ & $\begin{array}{l}\sigma_{0} \\
\text { के } \\
\text { के }\end{array}$ & 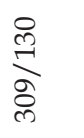 & $\frac{\infty}{\delta}$ & 总 & $\stackrel{\overrightarrow{0}}{\stackrel{\vec{\rho}}{\circ}}$ & 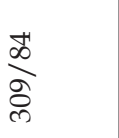 & 吕 & $\begin{array}{l}\stackrel{?}{1} \\
\text { 亏े } \\
\text { के }\end{array}$ & $\begin{array}{l}\infty \\
\frac{\infty}{\delta} \\
\frac{\infty}{n}\end{array}$ & 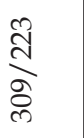 & $\begin{array}{l}\hat{\sigma} \\
\stackrel{1}{\sigma} \\
\text { ठे }\end{array}$ \\
\hline 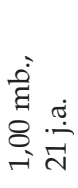 & 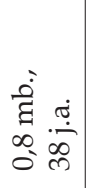 & 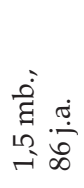 & 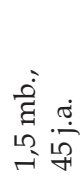 & 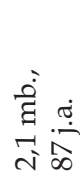 & 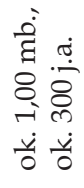 & 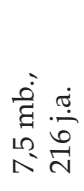 & 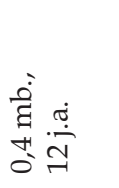 & 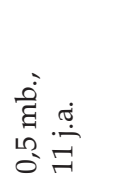 & 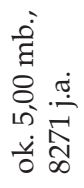 & 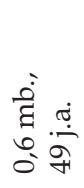 & 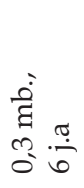 & 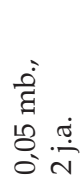 \\
\hline 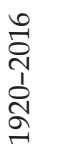 & 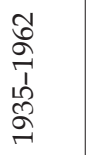 & 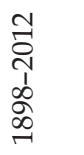 & 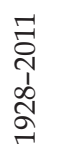 & 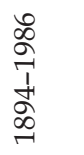 & 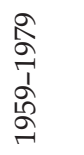 & 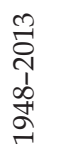 & $\begin{array}{l}\infty \\
2 \\
2 \\
7 \\
\frac{1}{11} \\
\stackrel{2}{2}\end{array}$ & $\begin{array}{l}2 \\
2 \\
\cdots \\
1 \\
b \\
\infty \\
\infty \\
=1\end{array}$ & 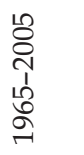 & 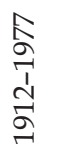 & 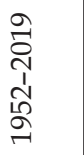 & 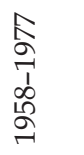 \\
\hline 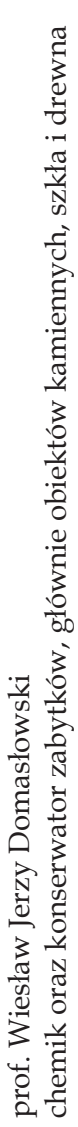 & 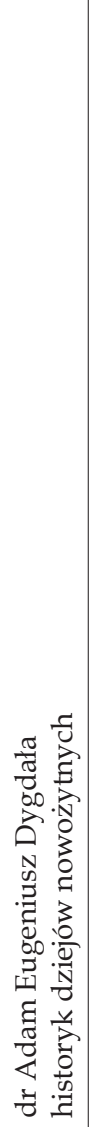 & 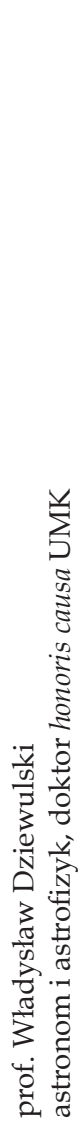 & 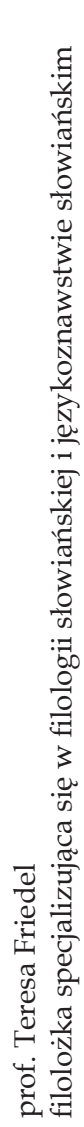 & 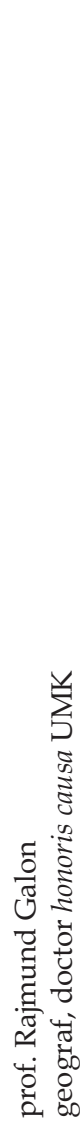 & 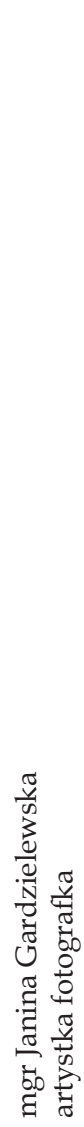 & 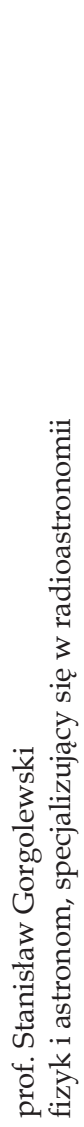 & 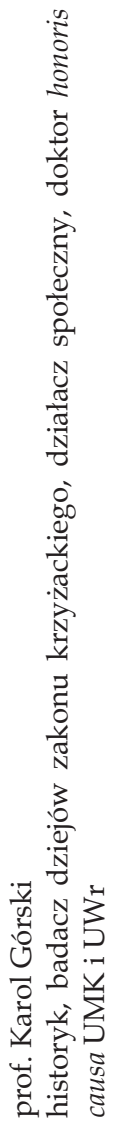 & 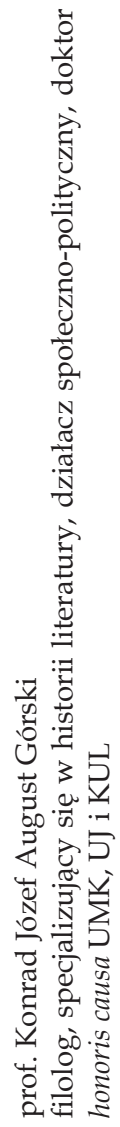 & 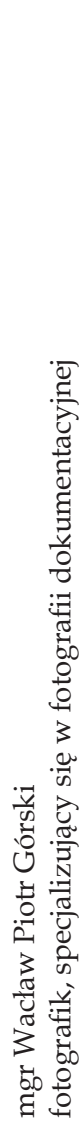 & 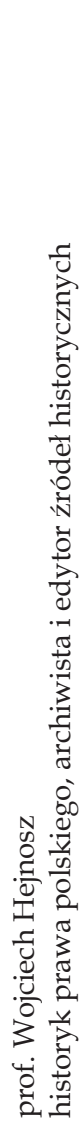 & 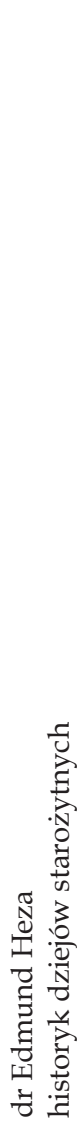 & 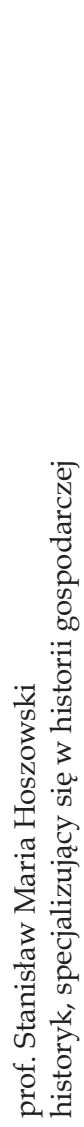 \\
\hline$\stackrel{\ddot{\sim}}{\sim}$ & $\ddot{ت}$ & $\stackrel{10}{\Gamma}$ & $\stackrel{0}{\oplus}$ & $\widehat{\overbrace{}}$ & $\stackrel{\infty}{\sim}$ & $\stackrel{0}{\sim}$ & ิ & $\vec{\lambda}$ & ㅊ & $\ddot{\sim}$ & $\stackrel{\sim}{\sim}$ & $\stackrel{\llcorner}{\sim}$ \\
\hline
\end{tabular}




\begin{tabular}{|c|c|c|c|c|c|c|c|c|c|c|}
\hline 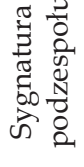 & $\begin{array}{l}\infty \\
0 \\
\hat{\sigma} \\
\delta \\
0 \\
0\end{array}$ & $\begin{array}{l}\infty \\
\text { के } \\
\text { के }\end{array}$ & 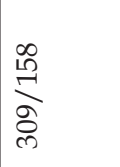 & $\begin{array}{l}\infty \\
\text { के } \\
\text { के }\end{array}$ & $\frac{2}{\frac{8}{2}}$ & 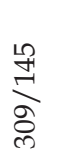 & $\frac{\bar{\sigma}}{\sigma}$ & 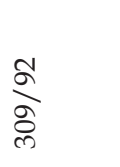 & 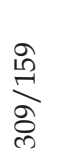 & 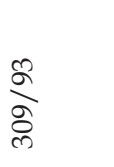 \\
\hline 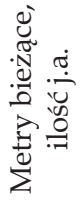 & 苞 & 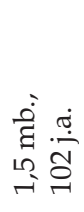 & 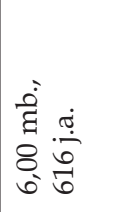 & 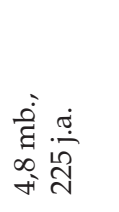 & 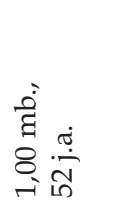 & 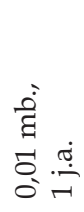 & 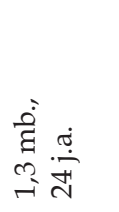 & 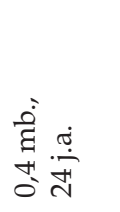 & 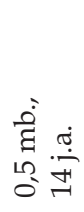 & 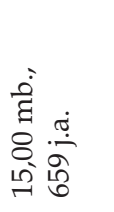 \\
\hline 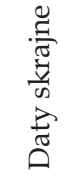 & 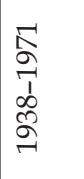 & $\begin{array}{l}\text { L } \\
8 \\
\uparrow \\
1 \\
\infty \\
\infty \\
\infty \\
\rightleftharpoons\end{array}$ & 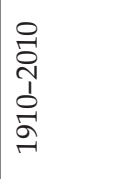 & 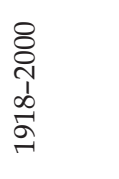 & 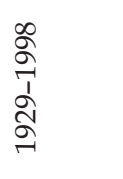 & 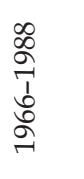 & 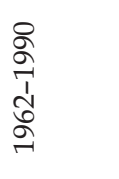 & 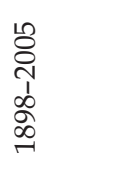 & $\begin{array}{l}\infty \\
\sigma \\
\overrightarrow{1} \\
\infty \\
\infty \\
\infty \\
\cdots\end{array}$ & 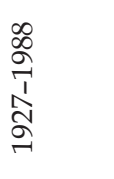 \\
\hline 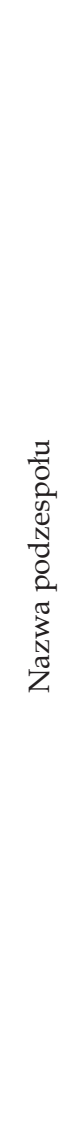 & 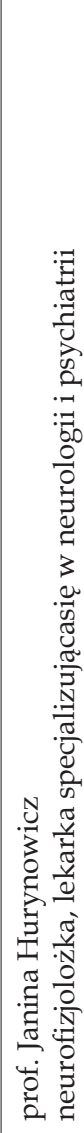 & 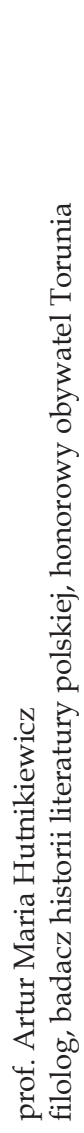 & 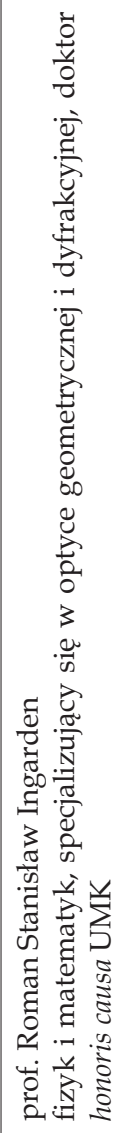 & 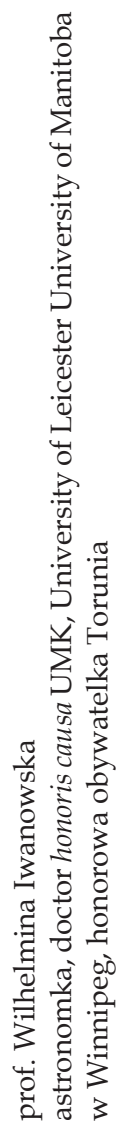 & 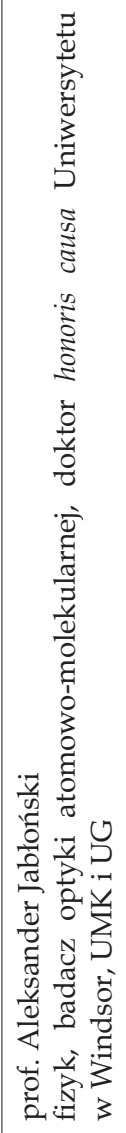 & 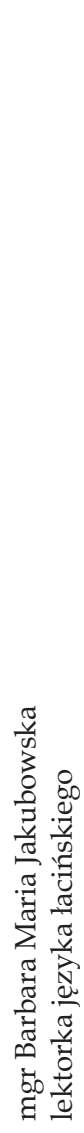 & 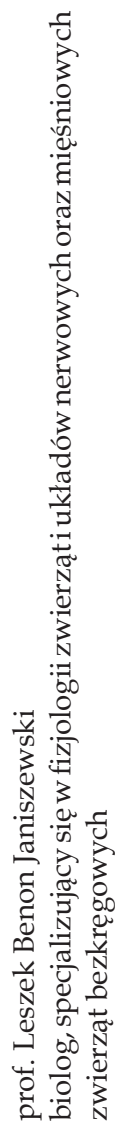 & 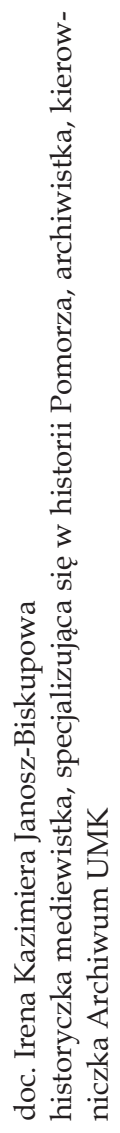 & 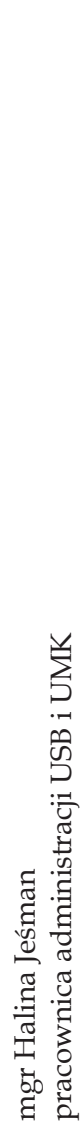 & 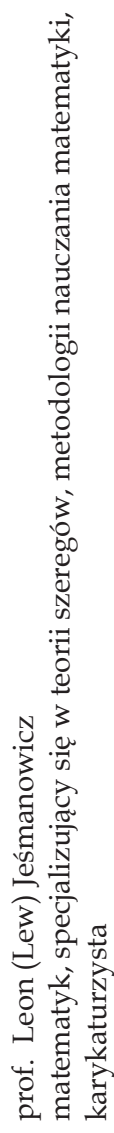 \\
\hline$\stackrel{\dot{2}}{1}$ & ส้ & הิ & 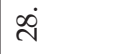 & ते & வி & ल & लें & ले & ஸేं & लि \\
\hline
\end{tabular}




\begin{tabular}{|c|c|c|c|c|c|c|c|c|c|c|}
\hline 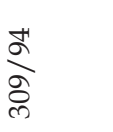 & $\begin{array}{l}\frac{L}{\sigma} \\
\frac{\sigma}{\delta} \\
\frac{\infty}{n}\end{array}$ & $\begin{array}{l}\text { ô } \\
\stackrel{-}{\sigma} \\
\text { } \\
\infty\end{array}$ & $\frac{\circ}{\circ}$ & $\frac{\hat{\infty}}{\stackrel{\infty}{=}}$ & $\begin{array}{l}\hat{\alpha} \\
\text { के } \\
\text { के }\end{array}$ & $\frac{\infty}{\stackrel{\infty}{=}}$ & 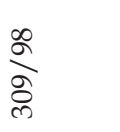 & $\begin{array}{l}\frac{a}{\sigma} \\
\frac{\partial}{\rho}\end{array}$ & $\begin{array}{l}\infty \\
\frac{\infty}{\infty} \\
\text { oे } \\
\infty\end{array}$ & $\begin{array}{l}\stackrel{8}{\ominus} \\
\stackrel{े}{\partial} \\
\text { }\end{array}$ \\
\hline 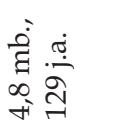 & 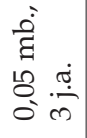 & 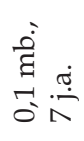 & 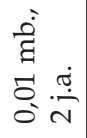 & 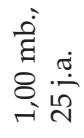 & 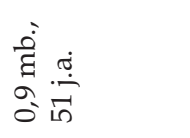 & 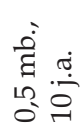 & 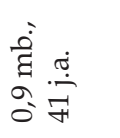 & 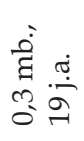 & 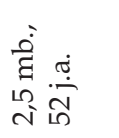 & 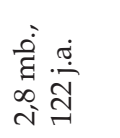 \\
\hline 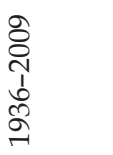 & 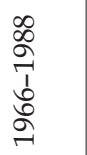 & 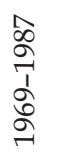 & ڤั & 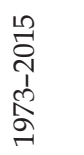 & 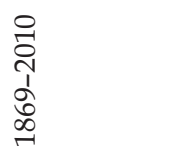 & 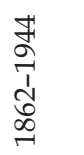 & 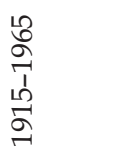 & 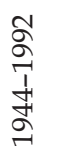 & $\begin{array}{l}0 \\
\stackrel{1}{0} \\
\text { 1 } \\
\hat{N} \\
\infty \\
\stackrel{0}{\rightleftharpoons}\end{array}$ & $\begin{array}{l}\stackrel{0}{5} \\
\stackrel{2}{7} \\
\frac{1}{2} \\
\stackrel{2}{2}\end{array}$ \\
\hline 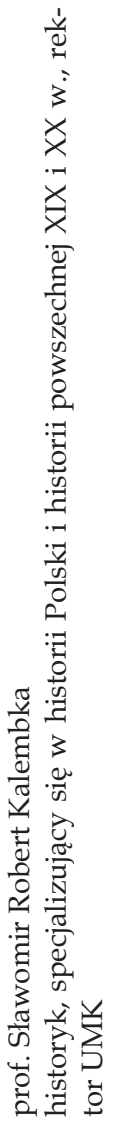 & 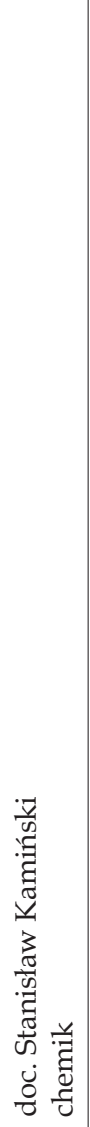 & 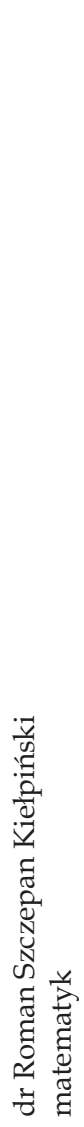 & 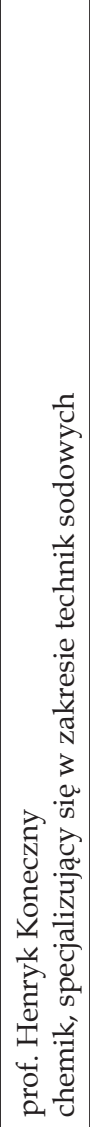 & 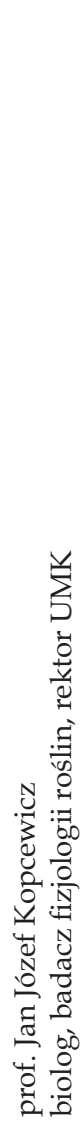 & 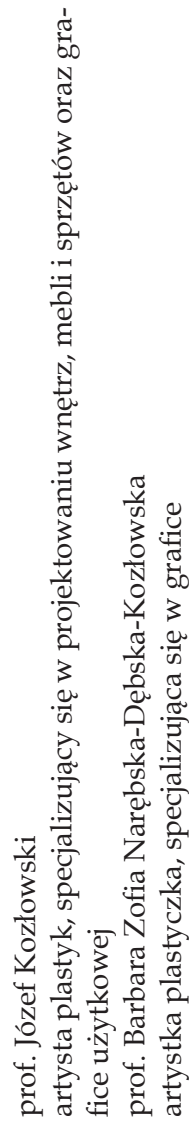 & 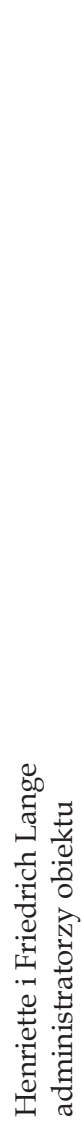 & 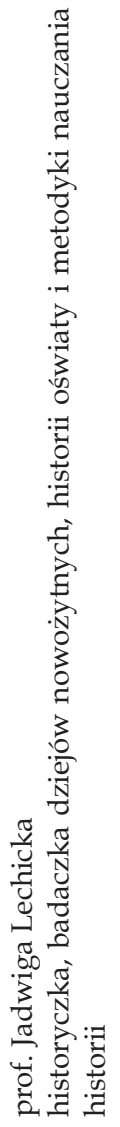 & 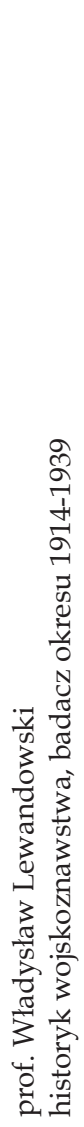 & 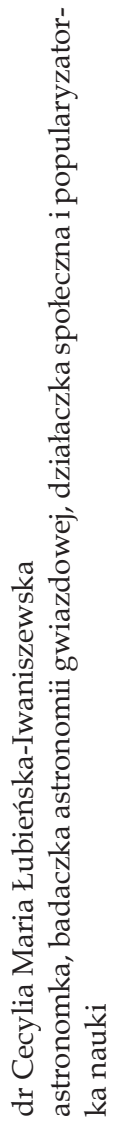 & 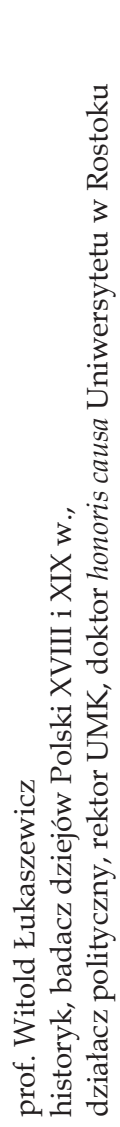 \\
\hline लें & के & $\begin{array}{l}\dot{\infty} \\
\prod^{\circ}\end{array}$ & ले & $\dot{q}$ & ஓं & ㄱำ & $\dot{\mathscr{H}}$ & मُ & டி & $\dot{\mathscr{H}}$ \\
\hline
\end{tabular}




\begin{tabular}{|c|c|c|c|c|c|c|c|c|c|c|}
\hline 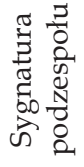 & $\begin{array}{l}\text { Jै } \\
\stackrel{-}{2} \\
\text { के } \\
\text { के }\end{array}$ & $\begin{array}{l}\stackrel{10}{0} \\
\stackrel{-}{\sigma} \\
\frac{0}{0}\end{array}$ & 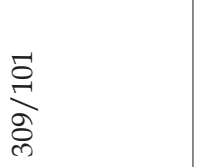 & $\begin{array}{l}\text { bे } \\
\frac{1}{\delta} \\
\text { हे }\end{array}$ & 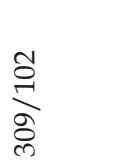 & $\begin{array}{l}\infty \\
\stackrel{1}{-} \\
\text { } \\
\text { के }\end{array}$ & 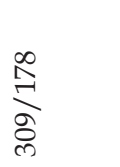 & $\begin{array}{l}\stackrel{+}{\circ} \\
\stackrel{-}{\sigma} \\
\text { ठे }\end{array}$ & 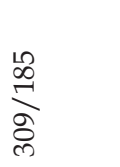 & $\begin{array}{l}\vec{b} \\
\stackrel{1}{\sigma} \\
\text { oे }\end{array}$ \\
\hline 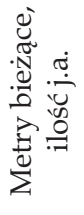 & 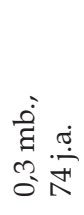 & 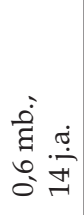 & 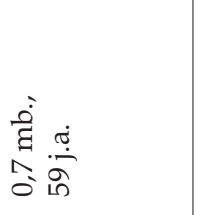 & 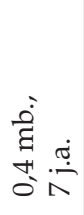 & 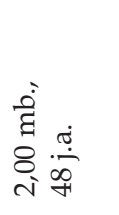 & 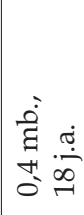 & 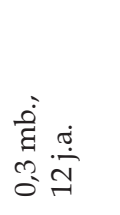 & 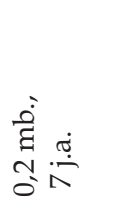 & 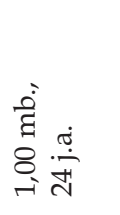 & 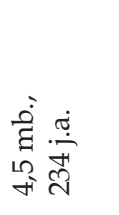 \\
\hline 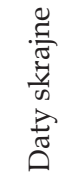 & 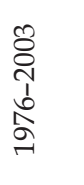 & 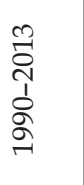 & 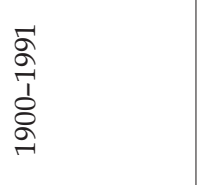 & 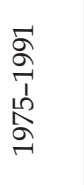 & 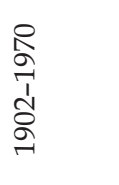 & 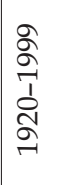 & 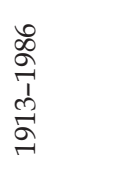 & 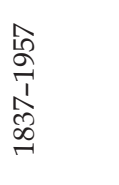 & $\begin{array}{l}0 \\
\text { o } \\
\text { 1 } \\
\text { bo } \\
\text { ô }\end{array}$ & 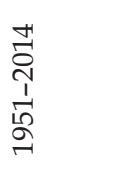 \\
\hline 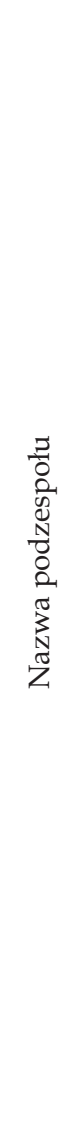 & 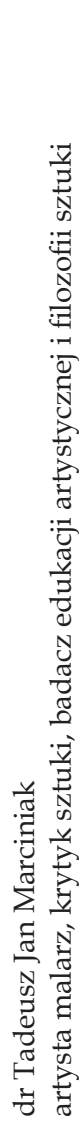 & 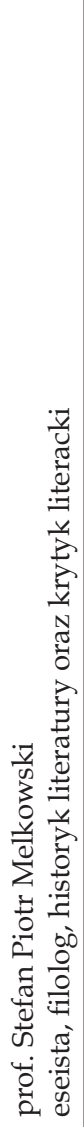 & 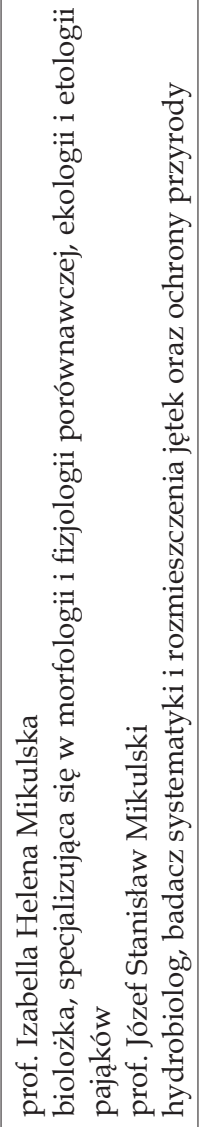 & 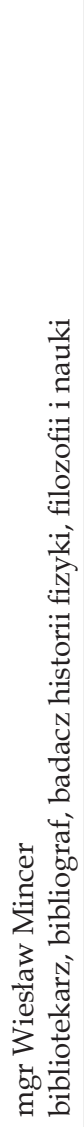 & 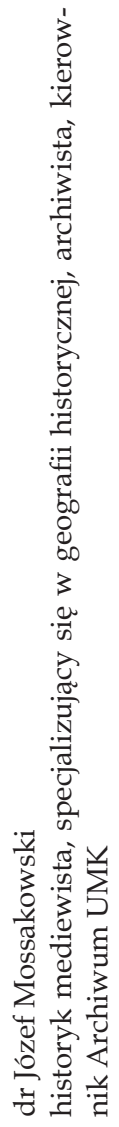 & 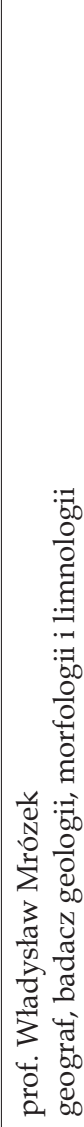 & 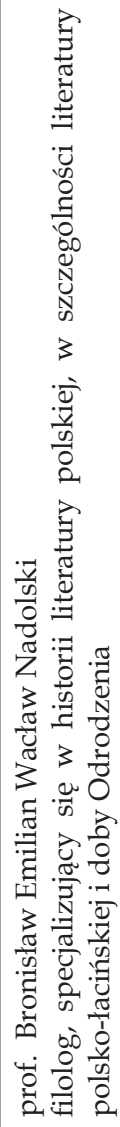 & 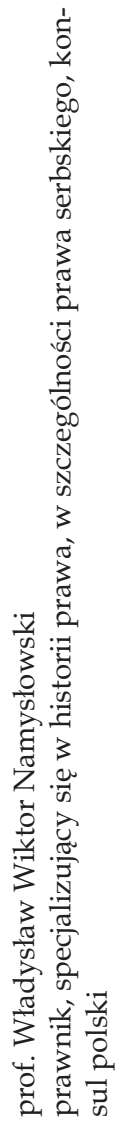 & 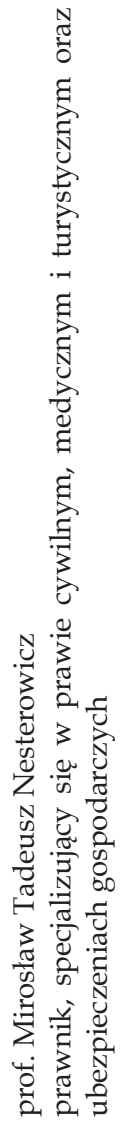 & 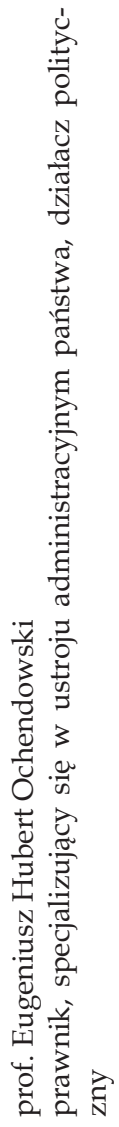 \\
\hline$\stackrel{\dot{2}}{1}$ & f & $\stackrel{\infty}{\mathfrak{r}}$ & جे & in & $\bar{n}$ & กี่ & กิ & மீ & ำ & மீं \\
\hline
\end{tabular}




\begin{tabular}{|c|c|c|c|c|c|c|c|c|c|c|c|}
\hline $\begin{array}{l}\stackrel{2}{\circ} \\
\frac{1}{2} \\
\text { के }\end{array}$ & 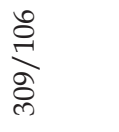 & $\begin{array}{l}\stackrel{\infty}{\infty} \\
\stackrel{े}{\partial} \\
\text { के }\end{array}$ & $\begin{array}{l}\stackrel{0}{\circ} \\
\stackrel{1}{\sigma} \\
\dot{0}\end{array}$ & $\begin{array}{l}\hat{0} \\
\stackrel{1}{\partial} \\
\text { oे }\end{array}$ & $\begin{array}{l}\infty \\
0 \\
\stackrel{1}{2} \\
\text { oे } \\
\text { के }\end{array}$ & $\begin{array}{l}\stackrel{g}{o} \\
\stackrel{\rho}{\sigma} \\
\text { oे }\end{array}$ & 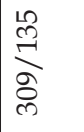 & 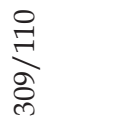 & $\frac{\infty}{\infty}$ & 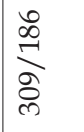 & $\begin{array}{l}\hat{0} \\
\stackrel{-}{\sigma} \\
\text { oे }\end{array}$ \\
\hline 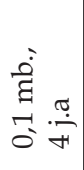 & 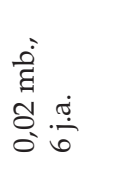 & 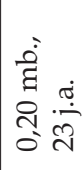 & 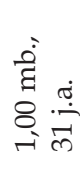 & 宫 & ¿ُ & 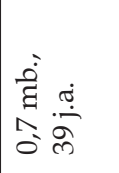 & 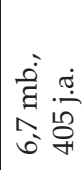 & 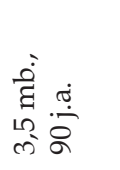 & 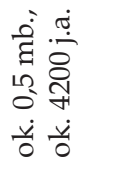 & 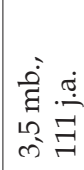 & 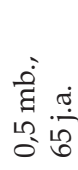 \\
\hline 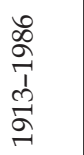 & 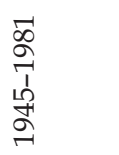 & 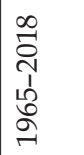 & 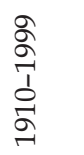 & $\begin{array}{l}0 \\
8 \\
7 \\
1 \\
\infty \\
\infty \\
-1\end{array}$ & 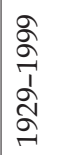 & $\begin{array}{l}\frac{2}{2} \\
2 \\
7 \\
1 \\
\infty \\
2 \\
\sigma\end{array}$ & 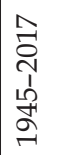 & 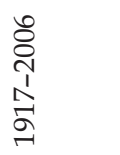 & 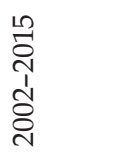 & 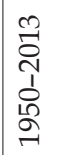 & 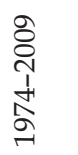 \\
\hline 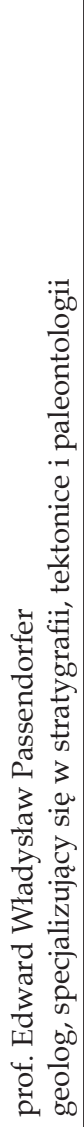 & 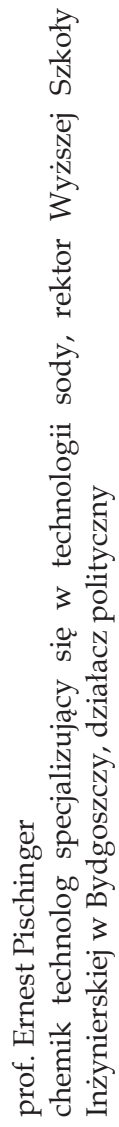 & 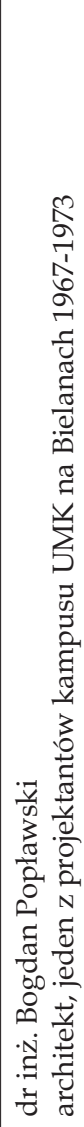 & 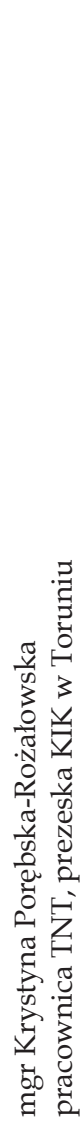 & 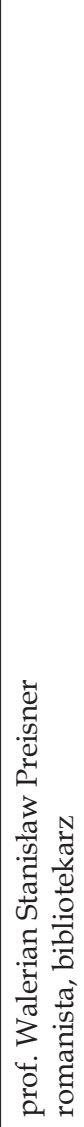 & 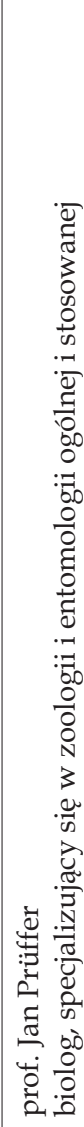 & 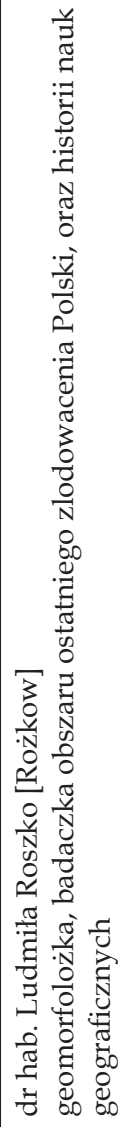 & 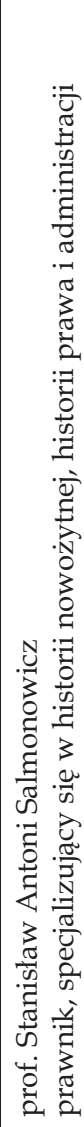 & 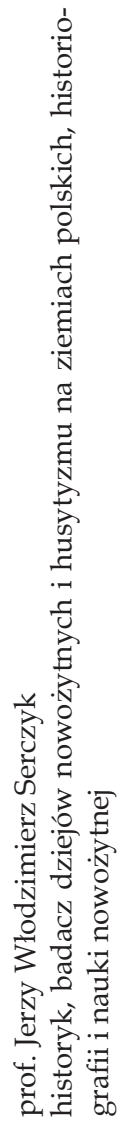 & 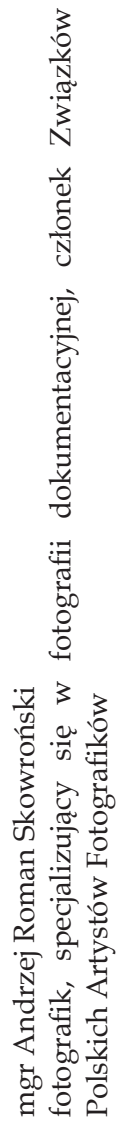 & 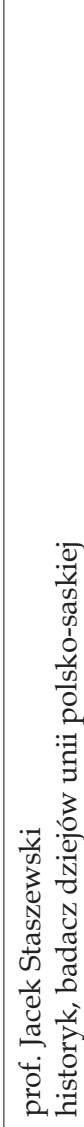 & 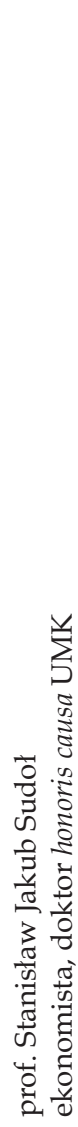 \\
\hline مिं & $\stackrel{\infty}{\circ}$ & மें & 8 & تु & ชู่ & ชु & تुં & 18 & ठ் & $\hat{\sigma}$ & $\infty \dot{0}$ \\
\hline
\end{tabular}


Weronika Krajniak

\begin{tabular}{|c|c|c|c|c|c|c|c|c|c|c|}
\hline 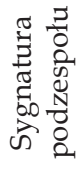 & $\begin{array}{l}\stackrel{1}{\infty} \\
\stackrel{-}{\sigma} \\
\text { के }\end{array}$ & 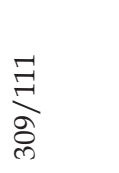 & 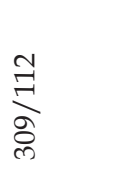 & $\frac{\infty}{=}$ & 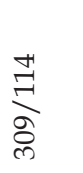 & $\stackrel{N}{\stackrel{N}{-}}$ & 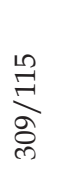 & 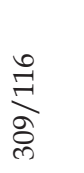 & 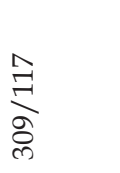 & $\begin{array}{l}\stackrel{\infty}{\sigma} \\
\stackrel{\sigma}{\sigma} \\
\stackrel{\infty}{\infty}\end{array}$ \\
\hline 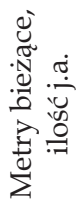 & 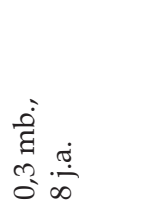 & 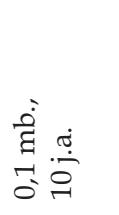 & 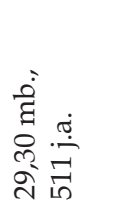 & 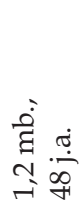 & 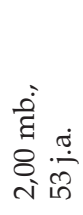 & 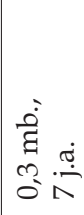 & 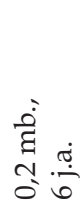 & 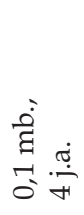 & 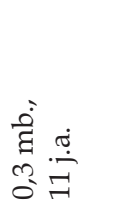 & 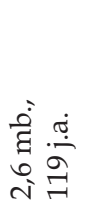 \\
\hline $\begin{array}{l}\frac{\tilde{E}}{\pi} \\
\frac{\pi}{\omega} \\
\frac{\vec{\pi}}{\sigma} \\
0\end{array}$ & 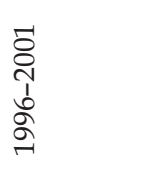 & 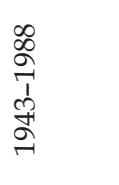 & 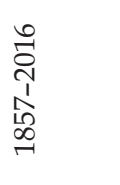 & 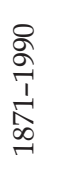 & 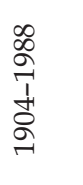 & 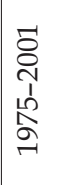 & $\begin{array}{l}\text { oి } \\
\text { ते } \\
1 \\
\infty \\
0 \\
2\end{array}$ & 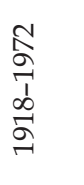 & 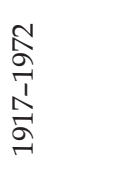 & 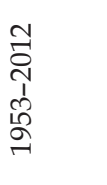 \\
\hline 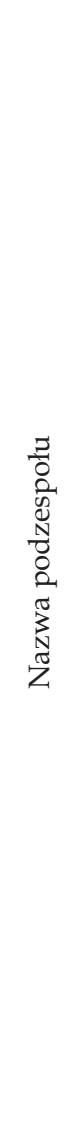 & 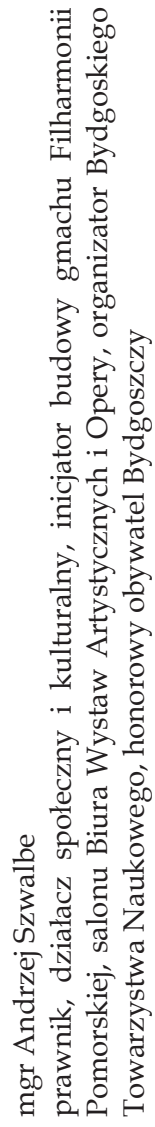 & 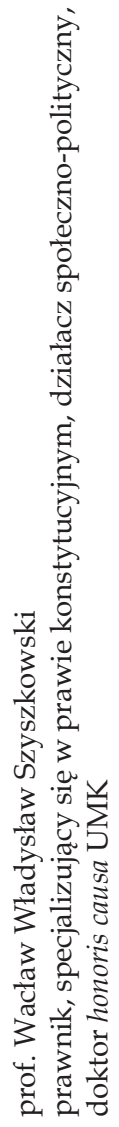 & 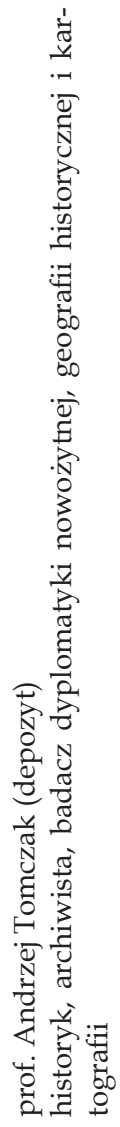 & 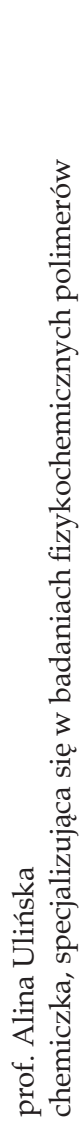 & 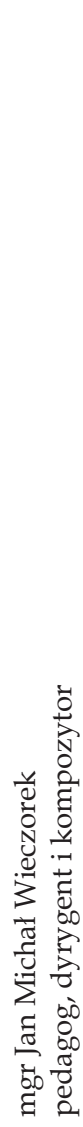 & 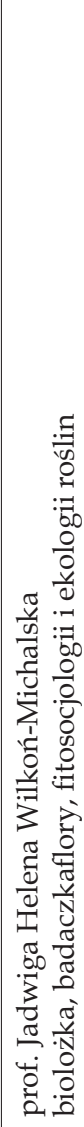 & 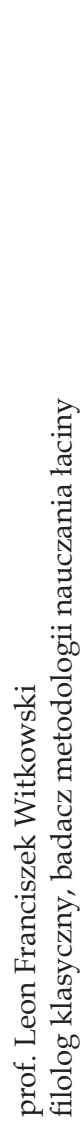 & 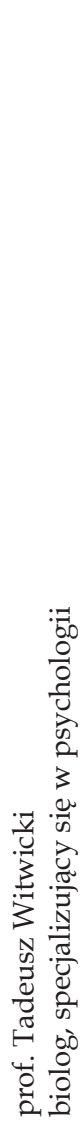 & 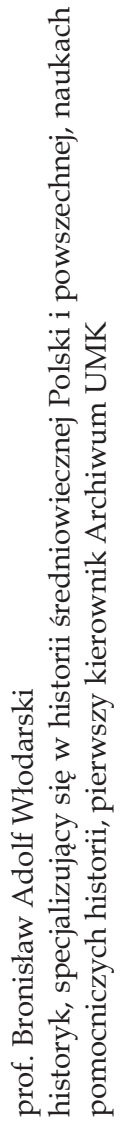 & 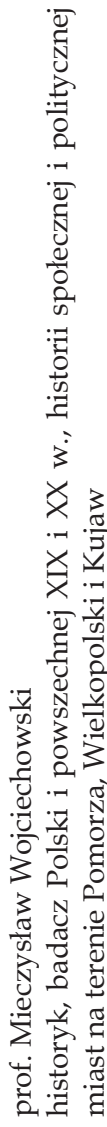 \\
\hline$\stackrel{\dot{2}}{\Omega}$ & gి & $\stackrel{R}{ }$ & $\dot{\mathrm{X}}$ & $\mathbb{N}$ & $\dot{N}$ & $\stackrel{\Delta}{ }$ & $\stackrel{10}{1}$ & $\stackrel{\circ}{\llcorner}$ & $\hat{N}$ & $\stackrel{\infty}{0^{\circ}}$ \\
\hline
\end{tabular}




\begin{tabular}{|c|c|c|c|}
\hline 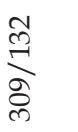 & $\frac{\infty}{\stackrel{\infty}{\sigma}}$ & 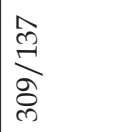 & 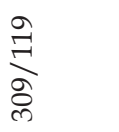 \\
\hline 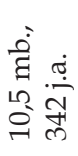 & 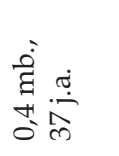 & 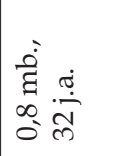 & 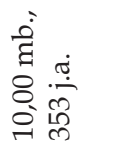 \\
\hline 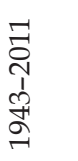 & 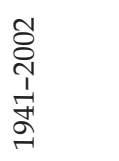 & 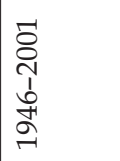 & 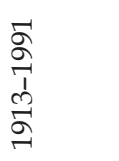 \\
\hline 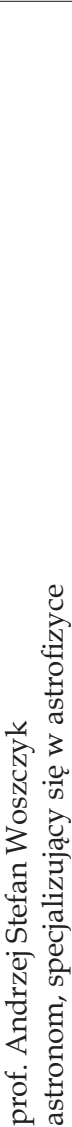 & 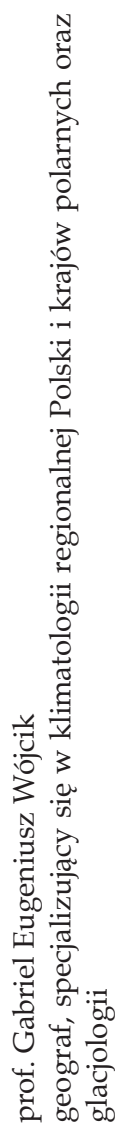 & 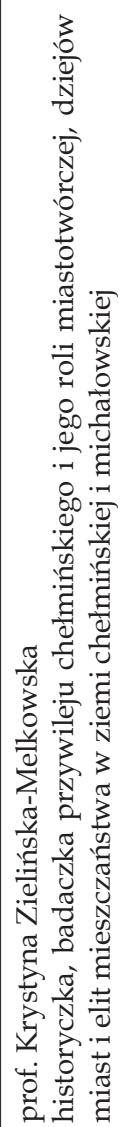 & 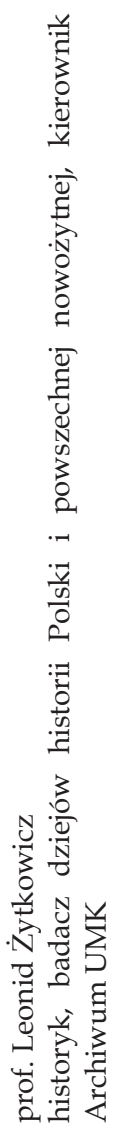 \\
\hline$\sigma^{\circ}$ & $\dot{\infty}$ & $\dot{\infty}$ & ஸ் \\
\hline
\end{tabular}




\section{Bibliografia}

\section{Źródła archiwalne}

Archiwum Państwowe w Toruniu

Akta profesora Mariana Biskupa, historyka z Torunia, sygn. 69/598.

Archiwum Uniwersytetu Mikołaja Kopernika w Toruniu

Akta własne - kontrola zewnętrzna [Archiwum Państwowe] (1953-2003), sygn. 2002/11.

Spuścizna mgr Marii Alexandrowicz 1899-1985, sygn. 309/73.

Spuścizna prof. Mariana Biskupa 1933-2012, sygn. 309/75.

Spuścizna prof. Tadeusza Czeżowskiego 1831-2012, sygn. 309/80.

Spuścizna prof. Władysława Dziewulskiego 1898-2012, sygn. 309/82.

Spuścizna prof. Rajmunda Galona 1894-1986, sygn. 309/83.

Spuścizna prof. Janiny Hurynowicz 1938-1971, sygn. 309/168.

Spuścizna prof. Romana Stanisława Ingardena 1910-2010, sygn. 309/158.

Spuścizna prof. Wilhelminy Iwanowskiej 1918-2000, sygn. 309/89.

Spuścizna mgr Haliny Jeśman 1868-1993, sygn. 09/159.

Spuścizna prof. Leona Jeśmanowicza 1927-1988, sygn. 309/93.

Spuścizna prof. Sławomira Kalembki 1936-2009, sygn. 309/94.

Spuścizna prof. Józefa Kozłowskiego i prof. Barbary Narębskiej-Dębskiej-Kozłowskiej 1869-2010, sygn. 309/97.

Spuścizna Henrietty i Friedricha Lange 1862-1944, sygn. 309/180.

Spuścizna dr. Tadeusza Jana Marciniaka 1976-2003, sygn. 309/164.

Spuścizna prof. Władysława Mrózka 1920-1999, sygn. 309/103.

Spuścizna mgr. Andrzeja Szwalbe 1996-2001, sygn. 309/217.

Spuścizna prof. Jana Michała Wieczorka 1904-1988, sygn. 309/114.

Biblioteka Główna Uniwersytetu Mikołaja Kopernika w Toruniu

Spuścizna prof. Tadeusza Czeżowskiego, sygn. Rps. 1585-1640, 2377-2398, 4770-4774.

Spuścizna prof. Władysława Dziewulskiego, sygn. Rps. 4785 oraz materiały nieopracowane.

Spuścizna prof. Rajmunda Galona, sygn. Rps. 2435-2463.

Spuścizna prof. Janiny Hurynowicz, sygn. Rps. 1376-1409, 4784.

Spuścizna prof. Wilhelminy Iwanowskiej, sygn. Rps. 4786 oraz materiały nieopracowane.

Spuścizna prof. Sławomira Kalembki, sygn. Rps. 4319-4321, 4538-4580.

Opracowania

Archiwum Uniwersytetu Mikotaja Kopernika w Toruniu. Informator o zasobie archiwalnym (Stan na dzień 31 grudnia 2017 roku), pod red. A Supruniuk, W. Krajniak, Toruń 2018.

Ciechanowski H., Spuścizna prof. Mariana Biskupa znajdująca się w Archiwum Uniwersytetu Mikołaja Kopernika $w$ Toruniu,http:// www.archiwa.net/index.php?option=com_remository\&Itemi$\mathrm{d}=35 \&$ func $=$ startdown\&id $=14$ (dostęp: 30 marca 2019 r.).

Duczkowska-Moraczewska H., Wykaz materiałów pracowników naukowych i dydaktycznych Uniwersytetu Mikołaja Kopernika w zbiorach Archiwum i Biblioteki UMK, [w:] Polsko-litewskie kontakty naukowe w świetle zbiorów archiwalnych i bibliotecznych, red. J. Arvaniti, A. Roszkowski, Warszawa 2004

Jabłońska M., Kierzkowska B., Spuścizny archiwalne kobiet uniwersytetu w zasobie Archiwum Uniwersytetu Mikołaja Kopernika w Toruniu i Bibliotece Uniwersyteckiej, [w:] Niewidzia(l)ne. Kobiety $i$ historia Uniwersytetu Mikotaja Kopernika w Toruniu, red. A. Derra, A.M. Kola, W. Piasek, Toruń 2020. 
Janosz-Biskupowa I., Archiwum Uniwersytetu M. Kopernika (1948-1968), „Zeszyty Naukowe Uniwersytetu Mikołaja Kopernika w Toruniu. Nauki Humanistyczno-Społeczne. Historia" 1969, t. 5(36).

Jędrzejczyk A., Matematyka i karykatura. Pasje Leona Jeśmanowicza (1914-1989), „Konteksty: polska sztuka ludowa: antropologia kultury, etnografia, sztuka", 2020, r. 74, nr 1-2.

Karpiesiuk R., Spuścizna rękopiśmienna Tadeusza Czeżowskiego, „Acta Universitatis Nicolai Copernici. Nauki Humanistyczno-Społeczne. Historia" 1991, t. 25(236).

Karpiesiuk R., Tadeusz Czeżowski w świetle toruńskich archiwaliów, [w:] Tadeusz Czeżowski (1889_ 1981): dziedzictwo idei: logika-filozofia-etyka, pod red. W. Tyburskiego i R. Wiśniewskiego, Toruń 2002.

Krajniak W., Jerzy Serczyk i jego materiaty w zasobie Archiwum Uniwersytetu Mikołaja Kopernika w Toruniu, "Archeion" 2018, t. 119.

Krajniak W., Rys historyczny Archiwum Uniwersytetu Mikotaja Kopernika w Toruniu, „Przegląd Archiwalno-Historyczny" 2017, t. 4.

Mycio A., Opracowanie archiwów prywatnych w Sekcji Rękopisów Biblioteki Uniwersyteckiej w Toruniu, "Archeion" 2018, t. 119.

Schinzel A., Pięćdziesiąt lat Olimpiady Matematycznej, „, Rocznik Polskiego Towarzystwa Matematycznego. Seria II: Wiadomości matematyczne" 2000, t. 36.

Wytyczne nr 12 Polskiej Akademii Nauk z 1990 r. dotyczące opracowania spuścizn archiwalnych po uczonych, zob. Zbiór przepisów archiwalnych wydanych przez Naczelna Dyrekcje Archiwów Państwowych w latach 1952-2000, wybór i oprac. M. Tarakanowska, E. Rosowska, Warszawa 2001. 
Weronika Krajniak

\title{
Co kryją spuścizny przechowywane w zasobie ArchiwumUniwersytetu Mikołaja Kopernika w Toruniu?
}

\begin{abstract}
Streszczenie
Artykuł jest podsumowaniem wieloletniej już tradycji przejmowania spuścizn po toruńskich uczonych do zasobu Archiwum Uniwersytetu Mikołaja Kopernika w Toruniu. Do dziś Archiwum UMK zgromadziło w swoim zasobie 82 spuścizny archiwalne po pracownikach Uniwersytetu oraz osobach związanych z Uczelnią, w tym 59 spuścizn profesorów, cztery spuścizny po docentach i doktorach habilitowanych, osiem spuścizn po doktorach, dziesięć po magistrach i jedna po Henrietcie i Friedrichu Lange, administratorach obiektu, o których wykształceniu nic nie wiemy. Autorka tekstu przyjrzała się bliżej wybranym spuściznom, które następnie poddała analizie. W podsumowaniu podkreśliła, że wszystkie spuścizny stanowią doskonałą bazę źródłową w procesie poznania twórczości i działalności naukowej aktotwórców, a niekiedy historii danej instytucji. Archiwalia zgromadzone w archiwach osobistych mogą zostać wykorzystane przez badaczy wielu dziedzin w różnych aspektach nauki. Do artykułu została załączona tabela $\mathrm{z}$ alfabetycznym wykazem spuścizn po pracownikach UMK oraz osobach związanych z uczelnią z lat 1966-2020.
\end{abstract}

Słowa kluczowe: spuścizna, archiwa osobiste, archiwa uczonych, materiały archiwalne, zasób archiwalny, Archiwum Uniwersytetu Mikołaja Kopernika

Weronika Krajniak

\section{What can be found in legacies kept in the fond of the Archive of Nicolaus Copernicus University in Torun?}

\begin{abstract}
The article describes the long-standing tradition of Nicolaus Copernicus University in Torun to include legacies left by Torun scientists in the fond of the University's Archive. So far, 82 archival legacies left by the University's staff and people associated with it were incorporated into the fond of the Archive of Nicolaus Copernicus University in Torun, including those of 59 professors, 4 docents, 8 scholars with a Ph.D. degree, 10 scholars with an MA degree, as well as one that had belonged to Henrietta and Friedrich Lange, members of the University's administrative staff, whose level of education remains unknown. The author examined the selected legacies and then performed detailed analysis. In the conclusion, she emphasized that all these legacies are an excellent source for learning about the creative and academic work of their previous owners, and sometimes even the history of the entire institution. Files collected in personal archives can be used by researchers from many disciplines for various scientific purposes. The article is supplemented by a table containing a list of legacies left by the University's staff and people associated with it in the years 1966-2020, in alphabetical order.
\end{abstract}

Keywords: legacy, personal archives, archives of scientists, archival materials, archival fond, the Archive of Nicolaus Copernicus University 